\title{
ISLAM BERKEMAJUAN DALAM PERSPEKTIF MUHAMMADIYAH
}

\author{
Mundzirin Yusuf \\ Universitas Islam Negeri Sunan Kalijaga Yogyakarta, Indonesia \\ E-mail: mundzirin@gmail.com \\ Hendro Widodo \\ Universitas Ahmad Dahlan Yogyakarta, Indonesia \\ E-mail: hwpgsd1960@gmail.com
}

\begin{abstract}
This study aims to describe the progressive Islam emerging in Muhammadiyah and to elaborate it in the view of Muhammadiyah. The results of this study are: 1) Islamic terms and ideas "progressive" substantially and historically are not new, because they are attached to the presence of the Muhammadiyah since its birth, and became popular when it was used as the theme of the $47^{\text {th }}$ Muhammadiyah Congress in Makassar, "Movement for Change Towards Progressive Indonesia"; 2) Progressive Islam sows the seeds of truth, kindness, peace, justice, benefit, prosperity, and the virtue of living dynamically for all humanity; Islam that upholds the glory of men and women without discrimination. Progressive Islam is a vision of Islam of Muhammadiyah that is not bound by the dimensions of space and time.
\end{abstract}

Keywords: Progressive Islam; vision of Islam; Muhammadiyah.

\section{Pendahuluan}

Muhammadiyah merupakan salah satu organisasi sosialkeagamaan Islam di Indonesia yang memiliki semangat pembaruan Islam, dan termasuk bagian dari organisasi Islam modernis di Indonesia. ${ }^{1}$ Muhammadiyah membawa Islam yang bekemajuan yang mengemban misi membangun masyarakat yang maju dalam

\footnotetext{
${ }^{1}$ Dharma Setyawan, "Analisis Hubungan Ijtihad dan Tajdid Pemikiran Ekonomi Terhadap Perkembangan Usaha (Studi Kasus pada Amal Usaha Organisasi Masyarakat Muhammadiyah)", Jurnal Ekonomi Islam, Vol. 2, No. 1 (2013), 107.
} 
berbagai sendi kehidupan, baik dalam kehidupan sosial kemasyarakatan, ekonomi, pendidikan, budaya, dan politik. Karena itu, Muhammadiyah terus berusaha sungguh-sungguh dan berikhtiar tanpa mengenal lelah untuk mewujudkan masyarakat Islam yang sebenar-benarnya. ${ }^{2}$

Sejak awal berdirinya, Muhammadiyah turut mewarnai perubahan kehidupan sosial keagamaan di Indonesia, melaksanakan dakwah amar makruf nahi mungkar (al-amr bi al-ma'rüf wa al-naby 'an al-munkar) secara nyata di masyarakat sehingga Muhammadiyah sering disebut sebagai gerakan pembaruan sosioreligius. ${ }^{3}$ Di sinilah umat Islam diharapkan menjadi pelopor kebaikan dalam mempraktikkan kehidupan dan membentuk komunitas sosial yang saleh sesuai denga ajaran Islam yang sebenar-benarnya. Inilah konsekuensi dari misi tauhid sosial, yang meskipun dalam praktiknya tidak sederhana karena akan besinggungan dengan ragam kepentingan yang melekat dalam diri manusia, namun Muhammadiyah berkomitmen sebagai pelopor gerakan Islam berkemajuan dan tetap konsisten berjuang amar makruf nahi mungkar secara riil dalam kehidupan bermasyarakat. ${ }^{4}$

Sejak Muhammadiyah berdiri, K.H. Ahmad Dahlan mendakwahkan Islam berkemurnian dan berkemajuan. Islam mendorong pengikutnya untuk selalu maju, tanpa kehilangan kemurnian akidah dan ibadahnya. Islam yang ramah dan rahmah, yang mengedepankan keramahan dan mengabaikan cara-cara kekerasan dalam berdakwah. Dakwah dan tajdid bagi Muham-madiyah merupakan jalan perubahan untuk mewujudkan Islam sebagai agama bagi kemajuan hidup umat manusia sepanjang zaman. Muhammadiyah memandang bahwa Islam merupakan agama yang mengandung nilai-nilai kemajuan untuk mewujudkan kehidupan umat manusia yang tercerahkan, yang unggul lahiriah dan ruhaniah. Oleh karena itu, dalam perspektif Muhamma-

2 M. Muchlas Abror, Mubammadiyah Mencerabkan Umat (Yogyakarta: Suara Muhammadiyah, 2015), 14.

3 Achmad Jainuri, Ideologi Kaum Reformis (Surabaya: LPAM, 2002), 147.

4 Ahmad Zainuddin, "Revitalisasi Nilai-nilai Sosial Tauhid dalam Merspons Realitas Kekinian”, ISLAMICA: Jurnal Studi Keislaman, Vol. 10, No. 2 (2016), 441-464. Lihat pula M. Amin Rais, Cakrawala Islam: Antara Cita dan Fakta (Bandung: Mizan, 1997), 13-14. 
diyah, Islam merupakan agama yang berkemajuan (din al ḥadärab), yang kehadirannya membawa rahmat bagi semesta kehidupan.

Slogan "Islam berkemajuan", sebelum tahun 2009 jarang terdengar, bahkan di kalangan Muhammadiyah sendiri. Ia baru diperkenalkan kembali, setelah cukup lama terpendam, dengan terbitnya buku berjudul Islam Berkemajuan: Kyai Ahmad Dablan dalam Catatan Pribadi Kyai Syuja' (2009). Buku yang ditulis oleh murid langsung K.H. Ahmad Dahlan ini di antaranya menjelaskan seperti apa karakter Islam yang dibawa oleh Muhammadiyah. Istilah "Islam berkemajuan" digunakan oleh Muhammadiyah pertama kali pada Muktamar di Yogyakarta tahun 2010, istilah ini lantas dipakai dan dipopulerkan untuk mengidentifikasi karakter keislaman Muhammadiyah. ${ }^{5}$

Secara etimologis, Muhammadiyah berasal dari bahasa Arab "Muhammad", yaitu nama nabi dan rasul Allah terakhir. Muḥam-mad itu sendiri berarti yang terpuji. Kemudian kata tersebut mendapatkan tambahan $y a^{\prime}$ nisbah, ${ }^{6}$ yang berfungsi untuk menjeniskan atau membangsakan, sehingga dengan tambahan tersebut Muhammadiyah bermakna pengikut. Jadi, Muhammadiyah adalah pengikut atau kelompok Nabi Muhammad (-yah dalam kata tersebut merupakan bentuk jamak).

Secara terminologis, Muhammadiyah adalah organisasi Islam yang didirikan oleh K.H. Ahmad Dahlan pada tanggal 8 Dhū alHijjah tahun $1330 \mathrm{H}$, bertepatan dengan tanggal 18 November 1912 M, di Yogyakarta. Muhammadiyah adalah organisasi gerakan dakwah Islam amar makruf nahi mungkar, tajdid, berakidah Islam, dan bersumber pada al-Qur'ān dan al-Sunnah. ${ }^{7}$ Sejak awal didirikannya, secara tegas Muhammadiyah mengikrarkan diri sebagai gerakan sosial keagamaan dengan memfokuskan diri pada kerja-kerja sosial, seperti halnya pendidikan, kesehatan, dan sebagainya. Sebagai gerakan Islam yang berwajah kultural dan transformatif, maka Muhammadiyah menjadi suatu gerakan Islam yang cepat diterima sehingga cepat meluas dalam kehidupan

\footnotetext{
5 Ahmad Najib Burhani, "Islam Nusantara vs. Islam Berkemajuan", http://nasional.sindonews.com/read/1019580/18/islam-nusantara-vsberkemajuan.

${ }^{6}$ Louis Ma'luf, Munjid fì al-Lughah wa al-A 'lām (Beirut: Dār al-Mashriq, 1986), 70.

${ }^{7}$ Lihat AD dan ART Muhammadiyah, Hasil Muktamar Muhammadiyah ke-45 di Malang tahun 2005, khususnya Bab I Pasal 2, dan Bab II Pasal 4.
} 
masyarakat Indonesia yang tengah mendambakan kemajuan pembaruan. Oleh karena itu, Muhammadiyah kemudian menjadi ideologi pergerakan bagi perubahan masyarakat. ${ }^{8}$

Gerakan pencerahan Muhammadiyah terus bergerak dalam mengemban misi dakwah dan tajdid untuk menghadirkan Islam sebagai ajaran yang mengembangkan sikap tengahan (wasatiyah), membangun perdamaian, menghargai kemajemukan, menghormati harkat martabat kemanusiaan laki-laki maupun perempuan, mencerdaskan kehidupan bangsa, menjunjung tinggi akhlak mulia, dan memajukan kehidupan umat manusia. Komitmen Muhammadiyah tersebut menunjukkan karakter gerakan Islam yang dinamis dan progresif dalam menjawab tantangan zaman, tanpa harus kehilangan identitas dan rujukan Islam yang autentik.

Slogan Islam berkemajuan menjadi lebih populer setelah diangkat menjadi tema Muktamar Muhammadiyah ke-47 tahun 2015 di Makassar. Din Syamsuddin menekankan visi Islam Berkemajuan agar ditanamkan oleh seluruh umat Islam di Indonesia. Islam Berkemajuan adalah pandangan dunia Muhammadiyah tentang Islam yang merupakan din al-ḥadärah, agama kemajuan atau peradaban. Hal ini disampaikan Din Syamsuddin dalam pembukaan Muktamar ke-47 Muhammadiyah dan Satu Abad Aisyiyah, di Makassar. Tulisan ini mengkaji lebih dalam Islam berkemajuan dalam perspektif Muhammadiyah, mengingat slogan tersebut bukanlah hal yang baru, melainkan kelanjutan dari gagasan K.H. Ahmad Dahlan sejak kelahiran Muhammadiyah seabad yang lalu. Hingga saat ini, visi itu masih relevan dengan kehidupan umat Islam, namun memerlukan revitalisasi dan kontekstualisasi dengan dinamika zaman. Tujuan tulisan ini untuk mendeskripsikan kemunculan istilah Islam berkemajuan di Muhammadiyah dan konsep Islam berkemajuan dalam pandangan Muhammadiyah.

\section{Mengenal K.H. Ahmad Dahlan}

Muhammadiyah berdiri pada tanggal 18 November 1912 bertepatan dengan tanggal 18 Dhū al-Hijjah $1330 \mathrm{H}$. Perintis berdirinya Muhammadiyah adalah K.H. Ahmad Dahlan (selanjutnya disebut Kiai Dahlan), kelahiran kampung Kauman, Yogyakarta pada tahun 1868 M dengan nama Muhammad Darwisy. Ayahnya

\footnotetext{
${ }^{8}$ Muhammad Damami, Akar Gerakan Muhammadiyah (Yogyakarta: Fajar Pustaka, 2004), $x$.
} 
adalah K.H Abu Bakar, seorang khatib Masjid Besar Kesultanan Yogyakarta, yang memiliki silsilah keturunan dari Maulana Malik Ibrahim. Ibunya bernama Siti Aminah, putri K.H. Ibrahim, penghulu Kesultanan Yogyakarta. ${ }^{9}$

Nama kecil Kiai Dahlan adalah Muhammad Darwisy. Kiai Dahlan merupakan anak keempat dari tujuh orang bersaudara. Dalam silsilahnya, Kiai Dahlan termasuk keturunan yang kedua belas dari Maulana Malik Ibrahim, seorang wali besar dan salah satu yang terkemuka di antara Walisongo, yang merupakan pelopor pertama dari penyebaran dan pengembangan Islam di tanah Jawa. ${ }^{10}$

Adapun silsilah lengkap Kiai Dahlan ialah Muhammad Darwisy b. K.H. Abu Bakar b. K.H. Muhammad Sulaiman b. Kiai Murtadla b. Kiai Ilyas b. Demang Djurung Djuru Kapindo b. Demang Djurung Djuru Sapisan b. Maulana Sulaiman Ki Ageng Gribig (Djatinom) b. Maulana Muhammad Fadlullah (Prapen) b. Maulana 'Ainul Yaqin b. Maulana Ishaq b. Maulana Malik Ibrahim. ${ }^{11}$

Silsilah di atas ditegaskan kembali oleh Hery Sucipto, bahwa Kiai Dahlan termasuk keturunan yang kedua belas dari Maulana Malik Ibrahim. Jika diruntut, silsilahnya tersebut ialah Maulana Malik Ibrahim, Maulana Ishaq, Maulana Ainul Yaqin, Maulana Muhammad Fadlullah (Sunan Prapen), Maulana Sulaiman Ki Ageng Gribing (Djatinom), Demang Djurung Djuru Sapisan, Demang Djurung Djuru Kapindo, Kiai Ilyas, Kiai Murtadla, K.H. Muhammad Sulaiman, K.H. Abu Bakar, dan Muhammad Darwisy (Ahmad Dahlan). ${ }^{12}$

Muhammad Darwisy ketika berumur 18 tahun, orang tuanya bermaksud menikahkannya dengan putri dari K.H. Muhammad Fadlil yang bernama Siti Walidah. Setelah orang tua dari kedua belah pihak berunding, maka pernikahan dilangsungkan pada bulan Dhū al-Hijjah tahun 1889 dalam suasana yang tenang. Siti Walidah inilah yang kelak dikenal sebagai Nyai Ahmad Dahlan, sosok

\footnotetext{
9 Ahmad Adaby Darban dan Mustafa Kemal Pasha, Muhammadiyah sebagai Gerakan Islam (Dalam Perspektif Historis dan Ideologis) (Yogyakarta: Pustaka Pelajar, 2000), 76.

${ }^{10}$ Kuntowijoyo, "Perlu Pengembangan Masyarakat", Salam, Vol. 4, No. 20, edisi 20-26 (Jumādā al-Ūlā 1410 H), 22.

11 Yunus Salam, Riwayat Hidup K.H. A. Dablan: Amal dan Perjuangannya (Jakarta: Depot Pengadjaran Muhammadijah, 1968), 6.

12 Hery Sucipto, K.H. Ahmad Dablan Sang Pencerah, Pendidik, dan Pendiri Muhammadiyah (Jakarta: Best Media Utama, 2000), 50.
} 
pendiri Aisyiyah dan pahlawan nasional. ${ }^{13}$ Dari perkawinannya dengan Siti Walidah, Kiai Dahlan memiliki enam orang anak, yaitu Djohanah, Siradj Dahlan, Siti Busyro, Irfan Dahlan, Siti Aisyah, Siti Zaharah. Setelah menikahi Siti Walidah, Kiai Dahlan pernah menikahi Nyai Abdullah, janda H. Abdullah. Ia juga pernah menikahi Nyai Rum, adik K.H. Munawwir dari Krapyak. Kiai Dahlan juga mempunyai putra dari pernikahannya dengan Nyai Aisyah (Adik Adjengan Penghulu) dari Cianjur. Anak laki-laki itu bernama Dandanah. Kiai Dahlan bahkan pernah menikah dengan Nyai Yasin dari Pakualaman Yogyakarta. ${ }^{14}$ Kiai Dahlan dimakamkan di Karang Kajen, Yogyakarta. ${ }^{15}$

\section{Cita-cita Islam Berkemajuan}

Organisasi Islam yang didirikan oleh Kiai Dahlan pada 1912 di Kota Yogyakarta itu memiliki tempat di hati masyarakat antara lain karena kepeloporannya dalam membangun institusi pendidikan dan amal-amal usaha sosial kemasyarakatan, yang terbilang modern yang benar-benar dapat memajukan dan memenuhi hajat hidup masyarakat. Kepeloporan dan amaliah yang konkret itu menjadi ciri khas dari gerakan Islam ini. Muhammadiyah menjadi penting dan strategis karena telah menghadirkan Islam yang bercorak pembaru dan berorientasi amaliah itu. Di tangan Muhammadiyah Islam menunjukkan transformasinya yang membumi pada awal $\operatorname{abad} 20 .^{16}$

Kiai Dahlan mendakwahkan Islam berkemurnian dan berkemajuan. Islam yang mendorong pengikutnya untuk selalu maju, tanpa kehilangan kemurnian akidah dan ibadahnya, Islam yang ramah dan rahmah, yang mengedepankan keramahan dan mengabaikan cara-cara kekerasan dalam berdakwah. Kiai Dahlan berkeyakinan bahwa Islam adalah agama yang tidak bertentangan dengan kemajuan dan ilmu pengetahuan. Sebaliknya, Islam mendorong pengikutnya untuk selalu maju dan tidak terbelakang. Karena keyakinannya tentang Islam berkemajuan itu, Kiai Dahlan tidak merasa gamang untuk mengadopsi model pendidikan yang

13 Adi Nugroho, K.H. Ahmad Dablan: Biografi Singkat 1868-1923 (Jogjakarta: Garasi House of Book, 2001), 20-21.

14 Ibid., 22.

15 Yunus Salam, Riwayat Hidup, 6.

16 Haedar Nashir, Revitalisasi Gerakan Mubammadiyah (Yogyakarta: BIGRAF Publishing, 2000), ix. 
diperkenalkan oleh pemerintah kolonial Hindia Belanda dengan berbagai modifikasi dan disesuaikan dengan semangat Islam berkemajuan, ketika para ulama dan umat Islam masih alergi dan menolak keras hal-hal yang berbau Barat yang dibawa oleh Belanda. Kiai Dahlan mengajarkan ilmu pengetahuan kepada para muridnya di samping tetap mengajarkan ilmu agama kepada mereka di suatu sekolah. Model sekolah yang dirintis oleh Kiai Dahlan ini di kemudian hari dijadikan sebagai model sekolah di Indonesia hingga sekarang. ${ }^{17}$

Kuntowijaya menegaskan bahwa langkah pembaruan yang bersifat reformis ialah merintis pendidikan modern yang memadukan pelajaran agama dan umum. Gagasan pendidikan yang dipelopori Kiai Dahlan merupakan pembaharuan karena mampu mengintegrasikan aspek "iman" dan "kemajuan", sehingga dihasilkan sosok generasi Muslim terpelajar yang mampu hidup di zaman modern tanpa terpecah kepribadiannya. ${ }^{18}$

Istilah berkemajuan sesungguhnya telah muncul sejak awal kelahiran Muhammadiyah tahun 1912. Di dalam Anggaran Dasar dan Rumah Tangga (AD/ART) Muhammadiyah tahun 1912 telah menyebutkan bahwa Muhammadiyah dimaksudkan untuk memajukan hal agama kepada anggota-anggotanya. ${ }^{19}$ Dijelaskan pula dalam Anggaran Dasar dan Rumah Tangga (AD/ART) Muhammadiyah 1914, bahwa maksud persyarikatan Muhammadiyah yaitu memajukan dan menggembirakan kehidupan (cara hidup) sepanjang kemauan agama Islam kepada lid-lid-nya.

Istilah berkemajuan menjadi lebih populer ketika dijadikan tema Muktamar Muhammadiyah, "Gerakan Perubahan Menuju Indonesia Berkemajuan”. Muhammadiyah bertekad untuk memberikan pencerahan. Gerakan pencerahan merupakan praksis Islam yang berkemajuan untuk membebaskan, memberdayakan dan memajukan kehidupan. Gerakan pencerahan dihadirkan untuk memberikan jawaban atas problem-problem kemanusiaan berupa kemiskinan, kebodohan, ketertinggalan dan persoalan-persoalan

17 Sakirman, "KH. Ahmad Dahlan dan Gerakan Pelurusan Arah Kiblat di Indonesia", Akademika; Jurnal Pemikiran Islam, Vol. 17, No. 2 (2012).

18 Rokhim, "Peran Organisasi Muhammadiyah dalam Bidang Pendidikan di Kecamatan Sukorejo Kabupaten Kendal", Jurnal Ilmiah Pendidikan Sejarah IKIP Veteran Semarang, Vol. 2, No. 1 (2014).

19 Pimpinan Pusat Muhammadiyah, Anggaran Dasar dan Rumah Tangga (AD/ART) Muhammadiyah 1912 (Yogyakarta: PP. Muhammadiyah, 1998), 1. 
lainnya yang bercorak struktural dan kultural. Gerakan pencerahan menampilkan Islam untuk menjawab masalah kekeringan rohani, krisis moral, kekerasan, terorisme, konflik, korupsi, kerusakan ekologis dan bentuk-bentuk kejahatan kemanusiaan. Gerakan pencerahan berkomitmen untuk mengembangkan relasi sosial yang berkeadilan tanpa diskriminasi, memuliakan martabat manusia lakilaki dan perempuan, menjunjung tinggi toleransi dan kemajemukan serta membangun pranata sosial yang utama.

Fajar Riza Ul Haq, Direktur Eksekutif Maarif Institute, pada tanggal 4 Agustus 2015 (sehari setelah pembukaan Muktamar Muhammadiyah) menulis gagasannya di kolom Kompas dengan judul "Kepemimpinan Muhammadiyah". Dalam esainya itu ia mengatakan bahwa Islam berkemajuan yang menjadi proposal Muhammadiyah memperlakukan Islam dalam kerangka nilai-nilai keadaban publik, bertaut erat dengan kepentingan masyarakat. Gagasan Islam berkemajuan sebagai formula jawaban organisasi ini atas kompleksitas persoalan kebangsaan dan kemanusiaan hari ini harus dilembagakan dan dibudayakan sehingga menjadi etos, tidak berhenti sebatas logos.

Selain itu, sejarawan Universitas Gadjah Mada (UGM), Bambang Purwanto, menyebut Muhammadiyah sebagai contoh produk persilangan budaya di dalam keberagaman yang melibatkan Islam, Jawa, Minangkabau dan modernitas Barat. Menurutnya, proses pembentukan kesadaran dan identitas Muhammadiyah ini berlangsung dalam proses modernisasi masyarakat Indonesia abad ke-20. Muhammadiyah generasi awal merupakan produk modernisasi Islam dengan denyut kosmopolitanisme lantaran tumbuh dalam spektrum keragaman "bangsa-bangsa" yang menjadi cikal-bakal Indonesia yang majemuk di kemudian hari. Menurut Vertovec dan Cohen kosmopolitanisme itu termanifestasi dalam perilaku terbuka dan kompetensi yang unggul dalam interaksi lintas budaya. Model Muhammadiyah kosmopolitan, kata Fajar Riza Ul Haq, memaknai cakupan dan ruang aktualisasi dakwah lebih kontekstual. Sejak awal Muhammadiyah sudah menggariskan bahwa berdakwah haruslah memajukan dan menggembirakan, seperti terbaca dalam anggaran dasar tahun 1914. Hal itu sejalan dengan pemikiran Kiai Dahlan bahwa inti Islam sejati adalah akal dan hati yang suci sehingga perbedaan kelompok dan bangsa tidak menjadi tembok penghalang 
melakukan solidaritas memerdekakan manusia dari penderitaan. Sebagai ikhtiar, Sidang Tanwir Muhammadiyah Tahun 2003 di Makassar menyetujui konsep dakwah kultural. Keputusan organisasi ini menandai adanya reorientasi visi dan strategi dakwah sesuai realitas kemajemukan budaya dan perbedaan identitas sosial masyarakat. $^{20}$

Karakter insan berkemajuan sangatlah diperlukan bagi bangsa Indonesia saat ini dan ke depan menuju Indonesia berkemajuan. Umat dan bangsa yang memiliki karakter berkemajuan selain berperilaku emas juga cerdas, berilmu, terampil, kreatif, inovatif, mandiri, berdaya saing, dan sifat-sifat maju lainnya sehingga menjadi insan berkeunggulan. Mereka tumbuh mekar menjadi insan yang bermasyarakat, berbangsa, dan berpergaulan global dengan karakter kuat dan maju, sekaligus memberi sibghah atau celupan yang positif selaku khalifah fi al-ard dalam menyebarkan risalah Islam yang berwawasan rạmatan lì al-'álamin. ${ }^{21}$

\section{Islam Berkemajuan dalam Pandangan Muhammadiyah}

Abdul Mu'ti dalam pengantar buku Kiai Syuja' mengemukakan lima fondasi Islam berkemajuan yang menjadi karakter Muhammadiyah. ${ }^{22}$ Pertama, tauhid yang murni. Muhammadiyah seringkali disebut sebagai gerakan Islam puritan, karena keteguhannya dalam mengajak masyarakat untuk senantiasa berpegang pada akidah yang lurus, bersih dari anasir yang merusak. Salah satu yang dilakukan untuk mengajak masyarakat kepada akidah yang murni dan meninggalkan perbuatan yang merusak iman adalah dengan melarang ziarah kubur. Bagi Muhammadiyah, larangan ziarah kubur adalah salah satu cara untuk memelihara kemurnian akidah, bukan substansi ajaran. Karena itu, jika umat Islam bisa menjaga kemurnian akidahnya dan melaksanakan ziarah kubur sesuai dengan sharīah Islam, maka ziarah kubur diperbo-

\footnotetext{
20 Selengkapnya, lihat Fajar Riza Ul Haq, "Kepemimpinan Muhammadiyah", dalam rubrik opini Kompas, 4 Agustus 2015; Lihat pula Saiful Mustofa, "Meneguhkan Islam Nusantara untuk Islam Berkemajuan: Melacak Akar Epistemologis dan Historis Islam (di) Nusantara", Epistemé: Jurnal Pengembangan Ilmu Keislaman, Vol. 10, No. 2 (2015), 413.

21 Pimpinan Pusat Muhammadiyah, "Membangun Karakter Indonesia Berkemajuan", Pidato Milad Muhammadiyah ke-104/107 tahun 2016 M/1437 H, Suara Mubammadiyah, Vol. 101, No. 20 (14-29 Muharram 1438 H), 28.

22 Kiai Syuja', Islam Berkemajuan: Kisab Perjuangan K.H. Abmad Dablan dan Mubammadiyah Masa Awal (Banten: Al-Wasath, 2009), x-xxi.
} 
lehkan. Kesadaran tauhid inilah yang melandasi perlawanan Muhammadiyah kepada kolonialisme Belanda. Kolonialisme adalah bertentangan dengan tauhid. Prinisp ini sekaligus menjelaskan bahwa sikap keras Muhammadiyah kepada Belanda bukan disebabkan karena mereka beragama Kristen, tetapi karena mereka menjajah dan mengeksploitasi sesama manusia.

Kedua, memahami al-Qur'ān dan Sunnah secara mendalam. Bagi Muhammadiyah, beragama harus berdasarkan al-Qur'ān dan Sunnah. Muhammadiyah melarang sikap taklid; beribadah tanpa dasar-dasar dan pemahaman yang mendalam. Muhammadiyah mengajak umat Islam untuk senantiasa berpegang teguh kepada alQur'ān dan Sunnah, dan menjadikannya sebagai dasar di dalam beribadah dan bermuamalah. Muhammadiyah berpendapat bahwa pemahaman terhadap al-Qur'ān dan Sunnah masih terbuka, begitu pula dengan pemahaman terhadap Islam. Muhammadiyah tidak menolak pendapat dan eksistensi mazhab, tetapi tidak mengikuti mazhab tertentu secara taken for granted.

Ketiga, melembagakan amal saleh yang fungsional dan solutif. Iman tidak sempurna tanpa amal saleh. Akan tetapi, bagi Muhammadiyah, amal saleh tidak semata-mata berupa ritual ibadah mabdah. Amal saleh adalah karya yang bermanfaat, merefleksikan kerahmatan Islam dan kasih sayang Allah. Dengan fondasi ini, Muhammadiyah bukanlah gerakan tadjid pemurniran an sich yang mengedepankan supremasi intelektualisme, tetapi gerakan amal. Pemikiran menjadi bagian tak terpisahkan dari gerakan amal. Amal saleh menurut Muhammadiyah bukanlah eskapisme; menunaikan ibadah dengan mengasingkan diri dari manusia dan berbagai permasalahan hidup dengan asyik makysuk ritual dan zikir spiritual. Amal saleh adalah amal yang bermanfaat dan solutif.

Keempat, berorientasi kekinian dan masa depan. Salah satu sebab kemunduran umat Islam adalah romatisme masa lalu yang berlebihan. Tidak ada keraguan bahwa kaum muslimin berhasil mencapai kejayaan melalui karya-karya yang mengagumkan. Para intelektual Muslim masa pertengahan ${ }^{23}$ mampu menyusun karyakarya cemerlang yang menyinari dunia dan menuntun masyarakat Barat yang masih hidup dalam gelap gulita. Namun, mengagumkan masa lalu yang sudah terkubur oleh waktu dapat menjadi "candu"

\footnotetext{
${ }^{23}$ Masa klasik Islam yang dimaksud yaitu 600-1250 M.
} 
yang membuat kita mabok dengan impian semu dan nostalgia yang dapat meninabobo. Sebagai bukti bahwa Muham-madiyah berpikir jauh ke masa depan adalah pada saat di mana masyarakat dan umat Islam masih hidup dalam gelap gulita kebodohan, kejumudan, takhayul dan mistisisme (tasawuf), para pemimpin Muhammadiyah tampil cemerlang dengan ide-ide, cita-cita dan langkah kongkret yang mencerahkan dengan membangun hospital (rumah sakit), armenhuis (rumah miskin) dan weeshuis (rumah yatim). Menawarkan ide mendirikan rumah sakit pada saat masyarakat masih berobat secara primitif kepada para dukun dan menolak dokter karena dianggap kafir memang tidak mudah. Akan tetapi, dengan tekad yang kuat, para pendiri Muhammadiyah bisa mewujudkan seluruh impian dan cita-cita mereka. Pada masanya, para pendiri Muhammadiyah tidak mampu membangun secara fisik yang mewah. Semua serba sederhana, tetapi dari kesederhanaan fisik itu terpancar semangat yang membara. Kini Muhammadiyah memiliki gedung-gedung amal usaha yang menjulang dan kokoh.

Kelima, bersikap toleran, moderat dan suka bekerjasama. Dalam diri sebagian masyarakat terdapat kesan bahwa Muhammadiyah adalah organisasi para elite; orang-orang kaya, intelektual, priyayi dan pejabat. Sebagian masyarakat menilai anggota Muhammadiyah bersikap elitis dan eksklusif. Fanatisme dan militansi menegakkan Islam murni yang berlebihan terkadang membuat sebagian anggota Muhammadiyah overreaktif, ofensif dan alienatif kepada mereka yang "berbeda keyakinan". Mereka tidak leluasa bergaul, karena masalah-masalah keagamaan yang sepele, kbiläfìyah furü'iyah, dan ecek-ecek. Penilaian dan kesan itu mungkin saja ada benarnya, tetapi salahnya jauh lebih besar. Indikasi bahwa Muhammadiyah toleran, saling menghormati dan akomodatif telah ditunjukkan oleh Kiai Dahlan dan para tokoh pendiri Muhammadiyah masa awal. Ketika ikhtiar mengubah kiblat melalui dialog gagal, Kiai Dahlan tidak memaksakan kehendak, ia memilih mendirikan musalla pribadi di dekat rumahnya. Ketika musalla itu pun pada akhirnya dirobohkan, Kiai Dahlan memilih pergi untuk menghindari konfrontasi.

Hal senada juga dikemukakan oleh Yunahar Ilyas, bahwa ada lima pondasi Islam Berkemajuan. ${ }^{24}$ Pertama, tauhid. Muham-

\footnotetext{
${ }^{24}$ Yunahar Ilyas, "Lima Pondasi Islam Berkemajuan”, Suara Muhammadiyah, Vol. 101, No. 19 (1-16 Oktober 2016), 34.
} 
madiyah sepanjang usianya terus melakukan pemurnian tauhid dengan dakwah yang mencerahkan dan santun. Ketauhidan yang murni pada akhirnya akan membawa masyarakat yang maju, dengan perilaku beragama yang efektif dan efisien. Dalam rangka mewujudkan tauhid yang murni, Muhammadiyah menolak semua bentuk sintesisme, sinkretisme dan relativisme agama. Namun, Muhammadiyah mengakui keberagaman sebagai sunnat Alläh yang harus dikelola menjadi kekuatan sinergi besar.

Kedua, pemahaman al-Qur'ān dan al-Ḥadīth secara independen, komprehensif dan integratif. Dalam hal ini, Muhammadiyah tidak terikat dengan aliran teologis, mazhab figh serta tarekat șūfiyah mana pun. Muhammadiyah tetap pada posisi sebagai Abl al-Sunnah wa al-Jamā'ah. Dalam setiap kebijakan, fatwa Muhammadiyah tetap mengindahkan dan mempertimbangkan berbagai sumber mazhab, sekte, dan aliran. Namun, hasil pembacaan menyeluruh kemudian dianalisis secara mendalam dengan multipendekatan serta ijtihad penuh ikhtiyat untuk dipilih yang paling räjĭh (kuat) dan compatible diterapkan dalam kehidupan hari ini dan masa depan.

Ketiga, tajdid. Muhammadiyah memandang bahwa tajdid memiliki dua sayap yang harus berjalan seimbang, yaitu pemurnian (purifikasi) dan dinamisasi (modernisasi). Purifikasi dalam ranah akidah, ibadah dan akhlak. Sementara itu, dinamisasi dalam semua aspek kehidupan yang sangat luas, meliputi bidang politik dan ekonomi untuk ditawarkan kepada negara.

Keempat, moderat (wasatiyah). Muhammadiyah selalu memilih jalan tengah (wasatijyah) di antara dua kutub ekstrem. Untuk menjadi moderat, harus dipahami dahulu pemahaman yang radikal dan liberal, lalu kemudian mengambil sikap. Aktualisasi dari moderat ini adalah tidak bersikap hegemonik serta selalu menghargai pendapat orang lain.

Kelima, gemar beramal. Sedikit bicara dan banyak bekerja itu watak Muhammadiyah. Sifat ini melekat pada setiap pimpinan, anggota, kader dan warga Muhammadiyah di mana saja. Oleh sebab itu, Amal Usaha Muhammadiyah selalu lahir dan tumbuh berkembang dari bawah, bukan atas instruksi dari atas. Bagi Muhammadiyah, beramal dan berilmu merupakan keharusan dalam rangka mencapai gerakan ilmu amaliah dan amal ilmiah. 
Haidar Nashir ${ }^{25}$ menegaskan bahwa ciri-ciri Islam yang berkemajuan adalah: Pertama, secara teologi, merujuk pada esensi ajaran Islam, yakni din al ḥadărah sebagai agama yang membangun peradaban. Banyak sekali ayat-ayat al-Qur'ān maupun Ḥadīth Nabi Muhammad yang merujuk pada pesan-pesan Islam yang berkemajuan, misalnya, firman Allah pada surat al-Hashr [59] ayat 18:

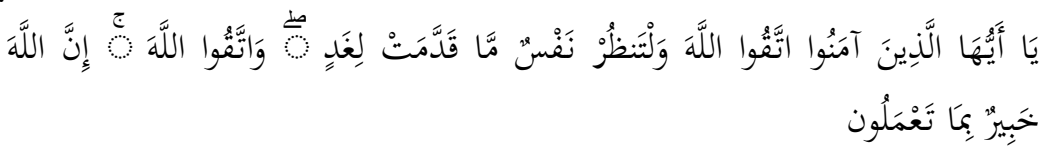

"Hai orang-orang yang beriman, bertakwalah kepada Allah dan hendaklah setiap diri memperhatikan apa yang telah diperbuatnya untuk hari esok (akhirat); dan bertakwalah kepada Allah, sesungguhnya Allah Maha Mengetahui apa yang kamu kerjakan".

Demikian pula terdapat dalam surat al-Ra'd [13] ayat 11:

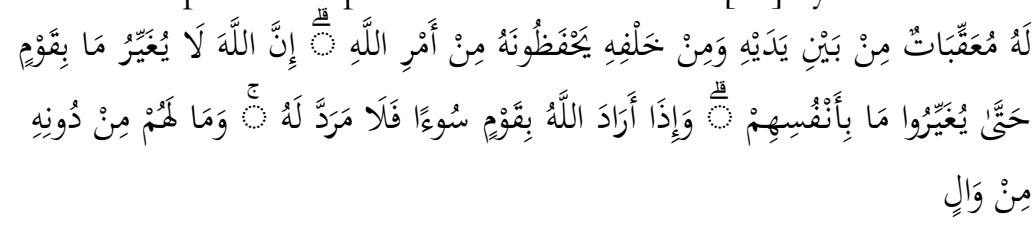

"Bagi manusia ada malaikat-malaikat yang selalu mengikutinya bergiliran, di muka dan di belakangnya, mereka menjaganya atas perintah Allah. Sesungguhnya Allah tidak mengubah keadaan suatu kaum sehingga mereka mengubah keadaan yang ada pada diri mereka sendiri. Dan apabila Allah menghendaki keburukan terhadap sesuatu kaum, maka tak ada yang dapat menolaknya; dan sekali-kali tak ada pelindung bagi mereka selain Dia".

Di dalam surat tersebut diajarkan, Tuhan tidak akan mengubah nasib sebuah kaum sehingga kaum itu yang mengubah dirinya sendiri. Ayat pertama dalam al-Qur'ān, Iqra', sebagaimana firman Allah pada surat al-'Alaq [96] ayat 1-5:

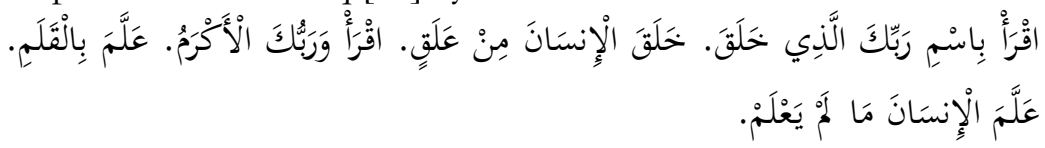

${ }^{25}$ Majalah Detik, Edisi 196, 31 Agustus 2015. 
"Bacalah dengan (menyebut) nama Tuhanmu Yang menciptakan, Dia telah menciptakan manusia dari segumpal darah. Bacalah, dan Tuhanmulah Yang Maha Pemurah, Yang mengajar (manusia) dengan perantaran kalam".

Kedua, dalam konteks sejarah, Islam berkemajuan itu digoreskan dalam jejak perjalanan nabi selama 23 tahun di Mekah dan Madinah. Atau dikenal dari masyarakat jahiliyah menjadi tamaddun atau masyarakat yang beradab. Sejarah Islam setelah itu selama enam abad lamanya mengukir sejarah kemajuan, sehingga disebut era kejayaan Islam. ${ }^{26}$ Dari semua itulah dikonstruksi ulang menjadi pandangan Muhammadiyah sebagai Islam berkemajuan. Hal itu menerje-mahkan nilai-nilai Islam berkemajuan dalam aksiaksi perubahan yang membawa reformisme dalam alam pikiran masyarakat, dari tradisional menjadi masyarakat yang maju dalam bidang pendidikan, dari tradisional menjadi pendidikan Islam modern. Begitu juga di bidang kesehatan dan pelayanan sosial, serta memelopori gerakan perempuan Islam yang berkemajuan, yakni 'Aisyiyah.

Muhammadiyah dengan pandangan Islam berkemajuan senantiasa berusaha mengintegrasikan nilai-nilai ke-Islaman dan keIndonesiaan. Muhammadiyah sebagai kekuatan strategis umat dan bangsa berkomitmen untuk membangun Negara Pancasila dengan pandangan Islam yang berkemajuan. Islam yang berkemajuan menyemaikan benih-benih kebenaran, kebaikan, kedamaian, keadilan, kemaslahatan, kemakmuran, dan keutamaan hidup secara dinamis bagi seluruh umat manusia. Islam yang menjunjung tinggi kemuliaan manusia baik laki-laki maupun perempuan tanpa diskriminasi.

Muhammadiyah dengan pandangan Islam yang berkemajuan bertekad berjuang di Negara Pancasila menunju Indonesia Berkemajuan sesuai dengan kepribadiannya, yaitu: 1) beramal dan berjuang untuk perdamaian dan kesejahteraan; 2) memperbanyak kawan dan meningkatkan persaudaraan (ukhuwwah Islamiyah); 3) memiliki pandangan luas dengan memegang teguh ajaran Islam; 4) bersifat keagamaan dan kemasyarakatan; 5) Memindahkan segala

${ }^{26}$ Dalam kajian sejarah Islam, dikenal tiga periode sejarah Islam, yaitu Masa Klasik: 600-1250; Masa Pertengahan: 1250-1800; dan Masa Modern: 1800-kini. Era Kejayaan Islam (The Islamic Golden Age/ Al-'Asr al-Dhababi al-Islämi termasuk bagian dari Masa Klasik). 
hukum, undang-undang, peraturan, serta dasar dan falsafah negara yang sah; 6) melakukan amar makruf nahi munkar dan menjadi teladan yang baik; 7) aktif dalam perkembangan masyarakat dengan maksud islăh dan pembangunan sesuai dengan ajaran Islam; 8) kerjasama dengan golongan Islam manapun juga dalam dalam usaha menyiarkan dan mengamalkan agama Islam, serta membela kepentingannya; 9) membantu pemerintah serta bekerjasama dengan golongan lain dalam memelihara dan membangun negara; dan 10) bersifat adil serta korektif ke dalam dan ke luar dengan bijaksana. ${ }^{27}$

Muhammadiyah memandang Islam sebagai jalan hidup (way of life) dan filosofi hidup, bukan sekadar gaya hidup. Esensi dari Islam lebih penting dari pada performative-nya. Esensi dari agama yang substantif antara lain terwujud dalam kesalehan diri dan kesalehan sosial, melakukan pengentasan kemiskinan dan keterbelakangan, pemberantasan korupsi, hidup bersahabat dengan umat lain, dan sikap tolong-menolong. Karena itu, Muhammadiyah menganjurkan kepada warganya untuk menekankan pentingnya esensi dan substansi Islam, bukan pada unsur life style dan performative. ${ }^{28}$

Islam adalah agama kemajuan dan keunggulan. Sebagai agama kemajuan (din al-hadàrah), Islam menganjurkan kepada pemeluknya untuk mampu menampilkan kehidupan yang maju dan dinamis, bukan kehidupan yang pasif dan stagnan. Islam menuntut umat Islam untuk mampu merebut kemajuan dan keunggulan dalam berkebudayaan dan berperadaban..$^{29}$ Islam berkemajuan adalah visi keislaman Muhammadiyah yang tidak terikat dimensi ruang, dan tidak terkait dimensi waktu. Oleh karena itu, akan menjadi terbatas, tetapi terikat kepada dimensi ketiga, yaitu dimensi gerak, menggerakkan kehidupan umat dan bangsa, "hari ini harus lebih

\footnotetext{
27 Pimpinan Pusat Muhammadiyah, Berita Resmi Muhammadiyah, Nomor 01, Tabun 2015-2020, September 2015 (Yogyakarta: PP. Muhammadiyah, 2015), 69-70.

28 Pimpinan Pusat Muhammadiyah, Muhammadiyah dan Isu-isu Strategis Keumatan, Kebangsaan, dan Kemanusiaan Universal (Yogyakrata: PP. Muhammadiyah, 2006), 4.

29 M. Din Syamsuddin, "Mendaki Jalan Ketakwaan Meraih Hidup Berkemajuan", Khutbah Idul Fitri 1436 H di Alun-alun Utara Keraton Yogyakarta.
} 
baik dari kemarin, hari yang akan datang harus lebih baik dari hari ini”, itulah Islam berkemajuan yang ingin kita mantapkan. ${ }^{30}$

Bagi Muhammadiyah, Islam yang dipeluk oleh mayoritas penduduk Indonesia merupakan agama yang mengandung ajaranajaran tentang kemajuan (din al-hadärah), yang berwatak progresif dan sesuai dengan alam pikiran masyarakat modern. Karenanya, Islam dapat menjadi sumber nilai yang penting dan utama bagi usaha-usaha membangun kehidupan kebangsaan menuju Indonesia berkemajuan. Indonesia berkemajuan memiliki banyak dimensi, yaitu: 1) berkemajuan dalam semangat, alam pikir, perilaku, dan senantiasa berorientasi ke masa depan; 2) berkemajuan untuk mewujudkan kondisi yang lebih baik dalam kehidupan material dan spiritual; dan 3) berkemajuan untuk menjadi unggul di berbagai bidang dalam pergaulan dengan bangsa-bangsa lain. ${ }^{31}$

\section{Aktualisasi Islam Berkemajuan Pascamuktamar Ke-47}

Muhammadiyah memandang bahwa Islam merupakan agama yang mengandung nilai-nilai kemajuan untuk mewujudkan kehidupan umat manusia yang tercerahkan. Kemajuan dalam pandangan Islam adalah kebaikan yang serba utama, yang melahirkan keunggulan hidup lahiriah dan ruhaniah. Adapun dakwah dan tajdid bagi Muhammadiyah merupakan jalan perubahan untuk mewujudkan Islam sebagai agama bagi kemajuan hidup umat manusia sepanjang zaman. Dalam perspektif Muhammadiyah, Islam merupakan agama yang berkemajuan (din al-ḥadärah), yang kehadirannya membawa rahmat bagi semesta kehidupan.

Islam yang berkemajuan menyemaikan benih-benih kebenaran, kebaikan, kedamaian, keadilan, kemaslahatan, kemakmuran, dan keutamaan hidup secara dinamis bagi seluruh umat manusia, yaitu Islam yang menjunjungtinggi kemuliaan manusia baik laki-laki maupun perempuan tanpa diksriminasi; Islam yang menggelorakan misi anti perang, anti terorisme, anti kekerasan, anti penindasan, anti keterbelakangan, dan anti terhadap segala bentuk pengrusakan di muka bumi seperti korupsi, penyalahgunaan kekuasaan,

\footnotetext{
${ }^{30}$ M. Din Syamsuddin, "Pidato Pimpinan Pusat Muhammadiyah Periode 20102015”, dalam Berita Resmi Mubammadiyah, No. 1, 2015-2020, September 2015 (Yogyakarta: PP. Muhammadiyah, 2015), 139.

31 Pimpinan Pusat Muhammadiyah, Indonesia Berkemajuan: Rekonstruksi Kebidupan Kebangsaan yang Bermakna (Yogyakarta: PP. Muhammadiyah, 2014), 11.
} 
kejahatan kemanusiaan, eksploitasi alam, serta berbagai kemungkaran yang menghancurkan kehidupan; Islam yang secara positif melahirkan keutamaan yang memayungi kemajemukan suku bangsa, ras, golongan, dan kebudayaan umat manusia di muka bumi. Muhammadiyah berkomitmen untuk terus mengembangkan pandangan dan misi Islam yang berkemajuan sebagaimana spirit awal kelahirannya tahun 1912.

Pandangan Islam yang berkemajuan yang diperkenalkan oleh pendiri Muhammadiyah telah melahirkan ideologi kemajuan, yang dikenal luas sebagai ideologi reformisme dan modernisme Islam, yang muaranya melahirkan pencerahan bagi kehidupan. Pencerahan (tanwir) sebagai wujud dari Islam yang berkemajuan adalah jalan Islam yang membebaskan, memberdayakan, dan memajukan kehidupan dari segala bentuk keterbelakangan, ketertindasan, kejumudan, dan ketidakadilan hidup umat manusia. Dengan pandangan Islam yang berkemajuan dan menyebarluaskan pencerahan, maka Muhammadiyah tidak hanya berhasil melakukan peneguhan dan pengayaan makna tentang ajaran akidah, ibadah, dan akhlak kaum Muslimin, tetapi sekaligus melakukan pembaruan dalam mu'ämalat al-dunyāwyjah yang membawa perkembangan hidup sepanjang kemauan ajaran Islam. Paham Islam yang berkemajuan semakin meneguhkan perspektif tentang tajdid yang mengandung makna pemurnian (purifikasi) dan pengembangan (dinamisasi) dalam gerakan Muhammadiyah, yang seluruhnya berpangkal dari gerakan kembali kepada al-Qur'ān dan al-Sunnah (al-rujū' ilā alQur'àn wa al-Sunnah) untuk menghadapi perkembangan zaman. ${ }^{32}$

Islam berkemajuan dapat ditransformasikan dalam proses menuju Indonesia berkemajuan jika didukung gerakan pemikiran dan peradaban (gerakan ide, pengembangan ilmu, pendidikan holisitik-integratif, dan penelitian berkemajuan) dan dipadukan dengan amal nyata melalui pemberdayaan institusi yang efektif dan dinamis. Islam berkemajuan mencerminkan pentingnya transformasi dari pemahaman dogmatis menuju pemahaman kritistransformatif yang kontekstual. Dengan begitu, Islam berkemajuan secara teologis menghendaki integrasi dua model kritik sekaligus, yaitu kritik teks dan konteks (realitas sosial) dengan senantiasa

\footnotetext{
32 Pimpinan Pusat Muhammadiyah, Tanfidz Keputusan Muktamar Satu Abad Mubammadiyah (Muktamar Muhammadiyah Ke-4O) (Yogyakarta: PP. Muhammadiyah, 2010), 15.
} 
merespons perkembangan ilmu pengetahuan dan relevansi sosial keumatan. Karena itu, Muhammadiyah perlu mereformasi sistem pendidikan dari yang bersifat tradisional menjadi modern, dari sekadar transfer of knowledge menjadi pembentukan karakter, akhlak mulia dan kultur berkemajuan, kemandirian, daya saing tinggi, dengan mengenyahkan "mental sebagai kaum terjajah dan pengemis". Karena itu, kualitas sistem pendidikan Islam harus terus ditingkatkan agar berkontribusi bagi peradaban keumatan yang lebih optimal. Islam dan Indonesia berkemajuan itu ibarat dua sisi mata uang yang bersifat simbiosis mutualistik. Tanpa kontribusi umat Islam, Indonesia mustahil berkemajuan. Sebaliknya, tanpa kehadiran "Indonesia merdeka", Islam Indonesia mustahil menjadi maju.

Indonesia berkemajuan teraktualisasi jika Islam berkemajuan bisa ditransformasikan dalam proses pembangunan mental spiritual bangsa dan didukung gerakan pemikiran, ilmu, riset, dan peradaban serta dipadukan dengan amal nyata dan penguatan budaya keumatan yang kokoh dan produktif, seperti budaya malu, disiplin, membaca, menulis, berkarya, budaya beramal saleh. Indonesia berkemajuan, tentu diharapkan dunia menjadi peradaban besar, jika nilai-nilai Islam rạ̣mah lì al-älamin dapat dipahami, dididikkan, dan disosialisasikan secara transformatif-kultural, dari pemahaman dogmatis menuju kritis-transformatif yang kontekstual. Dengan begitu, Islam berkemajuan secara teologis menghendaki integrasi dua model kritik sekaligus, yaitu kritik teks dan konteks (realitas sosial) dengan senantiasa merespons perkembangan ilmu pengetahuan dan relevansi sosial keumatan. ${ }^{33}$

Islam yang berkemajuan tentu tidak boleh berhenti sekadar jargon, isu, dan pernyataan normatif. Islam yang berkemajuan harus diwujudkan dalam kebudayaan yang berkemajuan baik dalam bentuk sistem nilai, sistem pranata, maupun sistem tingkah laku kolektif sehingga mendarah-daging dalam kehidupan seluruh warga Muhammadiyah pada khususnya dan umat Islam maupun masyarakat pada umumnya.

Muhammadiyah berkemajuan harus menjadi komitmen seluruh pimpinan dan anggota Muhammadiyah saat ini dan ke depan. Muhammadiyah lima tahun ke depan sebagaimana program hasil

33 Muhbib Abdul Wahab, "Menuju Islam dan Indonesia Berkemajuan", Republika, Rabu, 28 Desember 2016. 
Muktamar ke-47 menetapkan visi yang harus dicapai yaitu: (1) Terciptanya transformasi (perubahan cepat ke arah kemajuan) sistem organisasi dan jaringan yang maju, profesional, dan modern; (2) Berkembangnya sistem gerakan dan amal usaha yang berkualitas utama dan mandiri bagi terciptanya kondisi dan faktorfaktor pendukung terwujudnya masyarakat Islam yang sebenarbenarnya; serta (3) Berkembangnya peran strategis Muhammadiyah dalam kehidupan umat, bangsa, dan dinamika global. Secara khusus gerakan ekonomi harus menjadi perhatian penting dalam lima tahun ke depan agar Muhammadiyah makin kuat dan mandiri, tetapi gerakan ekonomi ini harus benar-benar membumi dan tidak model instan dan muluk-muluk.

Lima tahun ke depan, dalam kaitannya dengan gerakan pencerahan yang menjadi komitmen Muhammadiyah, dikembangkan Model Dakwah Pencerahan Berbasis Komunitas untuk diwujudkan secara meluas di seluruh struktur Persyarikatan; bagaimana menggarap komunitas kelas atas, menengah, bawah, dan komunitas khusus lainnya dengan misi dakwah yang meneguhkan dan mencerahkan. Dakwah komunitas tersebut merupakan transformasi atau reaktualisasi dari Gerakan Jamaah dan Dakwah Jamaah yang bersifat membebaskan, memberdayakan, dan memajukan. Ketiga proses strategis tersebut merupakan perwujudan dari gerakan pencerahan Muhammadiyah untuk kemajuan umat, bangsa, dan dunia kemanusiaan universal.

Beberapa program dijadikan prioritas sebagai program pengembangan sebagai bagian dari strategi pengembangan untuk mencapai visi Muhammadiyah 2020, yakni sebagai berikut. Pertama, pengembangan kuantitas dan kualitas Cabang-Ranting sebagai basis penguatan, pemberdayaan, dan perluasan gerakan Muhammadiyah di akar-rumput sebagai bagian penting dan strategis dalam mengembangkan kekuatan "civil Islam" (masyarakat madani, civil society) di masyarakat. Kedua, pengemba-ngan sistem gerakan yang ditekankan pada pengayaan dan penyebarluasan ideologi dan pemikiran yang menjadi basis bagi pengembangan nilai-nilai keagamaan, intelektualitas, dan praksis gerakan yang bersifat pembaruan sebagai bagian penting dan strategis bagi pengembangan tajdid Muhammadiyah untuk pencerahan masyarakat. Ketiga, pengembangan kualitas sumber daya anggota dan kader sebagai pelaku gerakan yang mampu mendinamisasi dan memperluas 
peran strategis Muhammadiyah dalam dinamika kehidupan umat, bangsa, dan percaturan global. Keempat, pengembangan amal usaha dan praksis sosial Muhammadiyah yang unggul dengan mengintensifkan dan memperluas program ekonomi, pemberdayaan masyarakat, dan gerakan jamaah sebagai basis kemandirian dan kekuatan strategis Muhammadiyah. Kelima, pengembangan model gerakan pencerahan Muhammadiyah ke dalam program berbasis komunitas yang bersifat membebaskan, memberdayakan, dan memajukan bagi kehidupan umat, bangsa, dan kemanusiaan universal. Keenam, pengembangan peran strategis Muhammadiyah dalam kehidupan bangsa dan negara serta percaturan global yang berbasis pada prinsip, kepribadian, kemandirian, keseimbangan, dan kemaslahatan sesuai misi utama Muhammadiyah.

Kesuksesan gerakan Muhammadiyah lima tahun ke depan dapat ditentukan oleh peran para pimpinan di seluruh tingkatan dan struktur Persyarikatan. Segenap anggota pimpinan di seluruh tingkatan harus mengerahkan segenap kemampuan disertai komitmen, kebersamaan, konsistensi, dan pengkhidmatan yang tinggi dalam menyukseskannya. Ukuran aktif dan berhasilnya kepemimpinan justru terletak pada pencapaian optimal amanah Muktamar. Seluruh ikhtiar, kemampuan, dan daya dukung dikerahkan secara optimal untuk melaksanakan program dan menjalankan amanat Muktamar. Dengan demikian fungsi kepemimpinan di setiap tingkatan benar-benar bekerja-nyata dan bergerak-nyata secara dinamis sejalan dengan komitmen dalam menunaikan amanah sebagai wujud keikhlasan dan pengkhidmatan, yang selama ini menjadi spirit dan etos kerja dalam memimpin Muhammadiyah. Dari pikiran dan kerja keras pimpinan Muhammadiyah itulah lima tahun ke depan dapat dicapai visi Muhammadiyah Berkemajuan. ${ }^{34}$

\section{Penutup}

Istilah dan pemikiran Islam Berkemajuan sesungguhnya secara substantif maupun kesejarahan bukanlah hal baru, karena melekat dengan kehadiran Muhammadiyah sejak kelahirannya. Jejak langkah pembaruan yang dipelopori Kiai Dahlan yang melahirkan Muhammadiyah sebagai gerakan tajdid sejatinya membawa misi

\footnotetext{
34 Haedar Nashir, "Langkah Muhammadiyah Berkemajuan Lima Tahun ke Depan”, Suara Muhammadiyah 17/100/1-15, September 2015.
} 
Islam yang berkemajuan. Kiai Dahlan sendiri banyak memperkenalkan kata "maju" atau "berkemajuan" dalam banyak kesempatan. Hal ini dibuktikan pula dalam AD/ART Muhammadiyah tahun 1912 dan 1914, dan menjadi populer ketika dijadikan tema Muktamar Muhammadiyah ke-47 di Makasar, dengan mengusung tema Muktamar, "Gerakan Perubahan Menuju Indonesia Berkemajuan".

Islam adalah agama kemajuan dan keunggulan. Sebagai agama kemajuan (din al-hadärah), Islam menganjurkan kepada pemeluknya untuk mampu menampilkan kehidupan yang maju dan dinamis, bukan kehidupan yang pasif dan stagnan. Islam yang berkemajuan menyemaikan benih-benih kebenaran, kebaikan, kedamaian, keadilan, kemaslahatan, kemakmuran, dan keutamaa hidup secara dinamis bagi seluruh umat manusia. Islam yang menjunjung tinggi kemuliaan manusia baik laki-laki maupun perempuan tanpa diskriminasi. Islam berkemajuan adalah visi keislaman Muhammadiyah yang tidak terikat dimensi ruang, dan tidak terkait dimensi waktu. Oleh karena itu, akan menjadi terbatas, dan terikat kepada dimensi ketiga, yaitu dimensi gerak; menggerakkan kehidupan umat dan bangsa, "hari ini harus lebih baik dari kemarin, hari akan datang harus lebih baik dari hari ini".

Aktualisasi Islam berkemajuan pascamuktamar ke-47 diwujudkan dalam berbagai program pengembangan, yaitu: Pertama, pengembangan kuantitas dan kualitas Cabang-Ranting sebagai basis penguatan, pemberdayaan, dan perluasan gerakan Muhammadiyah di akar-rumput sebagai bagian penting dan strategis dalam mengembangkan kekuatan "civil Islam" (masyarakat madani, civil society) di masyarakat. Kedua, pengembangan sistem gerakan yang ditekankan pada pengayaan dan penyebarluasan ideologi dan pemikiran yang menjadi basis bagi pengembangan nilai-nilai keagamaan, intelektualitas, dan praksis gerakan yang bersifat pembaharuan sebagai bagian penting dan strategis bagi pengembangan tajdid Muhammadiyah untuk pencerahan masyarakat. Ketiga, pengembangan kualitas sumber daya anggota dan kader sebagai pelaku gerakan yang mampu mendinamisasi dan memperluas peran strategis Muhammadiyah dalam dinamika kehidupan umat, bangsa, dan percaturan global. Keempat, pengembangan amal usaha dan praksis sosial Muhammadiyah yang unggul dengan mengintensifkan dan memperluas 
program ekonomi, pemberdayaan masyarakat, dan gerakan jamaah sebagai basis kemandirian dan kekuatan strategis Muhammadiyah. Kelima, pengembangan model gerakan pencerahan Muhammadiyah ke dalam program berbasis komunitas yang bersifat membebaskan, memberdayakan, dan memajukan bagi kehidupan umat, bangsa, dan kemanusiaan universal. Keenam, pengembangan peran strategis Muhammadiyah dalam kehidupan bangsa dan negara serta percaturan global yang berbasis pada prinsip, kepribadian, kemandirian, keseimbangan, dan kemaslahatan sesuai misi utama Muhammadiyah.

\section{Daftar Rujukan}

Abror, M. Muchlas. Muhammadiyah Mencerabkan Umat. Yogyakarta: Suara Muhammadiyah, 2015

Burhani, Ahmad Najib. "Islam Nusantara vs. Islam Berkemajuan", http://nasional.sindonews.com/read/1019580/18/islamnusantara-vs-berkemajuan.

Darban, Ahmad Adaby dan Mustafa Kemal Pasha. Muhammadiyah sebagai Gerakan Islam (Dalam Perspektif Historis dan Ideologis). Yogyakarta: Pustaka Pelajar, 2000.

Damami, Muhammad. Akar Gerakan Muhammadiyah. Yogyakarta: Fajar Pustaka, 2004.

Haq, Fajar Riza Ul. "Kepemimpinan Muhammadiyah", Kompas, 4 Agustus 2015.

Ilyas, Yunahar. "Lima Pondasi Islam Berkemajuan", Suara Muhammadiyah, Vol. 101, No. 19, 1-16 Oktober 2016.

Jainuri, Achmad. Ideologi Kaum Reformis. Surabaya: LPAM, 2002.

Kuntowijoyo. "Perlu Pengembangan Masyarakat", Salam, No. 20, tahun IV, edisi 20-26, Jumādā al-Ūlā $1410 \mathrm{H}$.

Ma'luf, Louis. Munjid fì al-Lughah wa al-A'lām. Beirut: Dār al Mashriq, 1986.

Moleong, Lexy J. Metode Penelitian Kualitatif. Bandung: Remaja Rosdakarya, 2007.

Miles, M. B. \& Huberman, A. M. Qualitative Data Analysis: A Sourcebook of New Methods Sage. London: Beverly Hills, 1994.

Nashir, Haedar. Revitalisasi Gerakan Mubammadiyah. Yogyakarta: BIGRAF Publishing, 2000.

----. "Langkah Muhammadiyah Berkemajuan Lima Tahun ke Depan”, Suara Muhammadiyah, 17/100/1-15 September 2015. 
Nugroho, Adi. K.H. Ahmad Dablan: Biografi Singkat 1868-1923. Jogjakarta: Garasi House of Book, 2001.

Pimpinan Pusat Muhammadiyah. Anggaran Dasar dan Rumah Tangga (AD/ART) Mubammadiyah 1912. Yogyakarta: PP. Muhammadiyah, 1998.

-----. "Membangun Karakter Indonesia Berkemajuan", pidato disampaikan pada Milad Muhammadiyah ke-104/107 tahun 2016 M/1437 H, Suara Mubammadiyah, Vol. 101, No. 20, 14-29 Muḥarram $1438 \mathrm{H}$.

----- Berita Resmi Mubammadiyah, No. 1, Tabun 2015-2020, September 2015. Yogyakarta: PP. Muhammadiyah, 2015.

----- Muhammadiyah dan Isu-isu Strategis Keumatan, Kebangsaan, dan kemanusiaan Universal. Yogyakrata: PP. Muhammadiyah, 2006.

-----. Indonesia Berkemajuan: Rekonstruksi Kebidupan Kebangsaan yang Bermakna. Yogyakarta: PP. Muhammadiyah, 2014.

-----. Tanfidz Keputusan Muktamar Satu Abad Muhammadiyah (Muktamar Mubammadiyah Ke 40). Yogyakarta: PP. Muhammadiyah, 2010.

Rais, M. Amin. Cakrawala Islam: Antara Cita dan Fakta. Bandung: Mizan, 1997.

Rokhim. "Peran Organisasi Muhammadiyah Dalam Bidang Pendidikan di Kecamatan Sukorejo Kabupaten Kendal," Jurnal Ilmiah Pendidikan Sejarah IKIP Veteran Semarang, Vol. 2, No. 1, Nopember 2014.

Sakirman. "KH. Ahmad Dahlan dan Gerakan Pelurusan Arah Kiblat di Indonesia", Akademika: Jurnal Pemikiran Islam, Vol. 17, No. 2, 2012.

Salam, Yunus. Riwayat Hidup K.H. A. Dablan: Amal dan Perjuangannya. Jakarta: Depot Pengadjaran Muhammadijah, 1968.

Setyawan, Dharma. "Analisis Hubungan Ijtihad dan Tajdid Pemikiran Ekonomi terhadap Perkembangan Usaha (Studi kasus Pada Amal Usaha Organisasi Masyarakat Muhammadiyah)", Jurnal Ekonomi Islam, Vol. 2, No. 1, 2013.

Sucipto, Hery. K.H. Ahmad Dablan Sang Pencerab: Pendidik dan Pendiri Muhammadiyah. Jakarta: Best Media Utama, 2000.

Sugiyono. Metodologi Penelitian Kuantitatif dan Kualitatif. Bandung: Alfabeta, 2008. 
Syamsudin, M. Din. "Mendaki Jalan Ketakwaan Meraih Hidup Berkemajuan", Khutbah Idul Fitri 1436 H, di Alun-alun Utara Keraton Yogyakarta.

----. "Pidato Pimpinan Pusat Muhammadiyah Periode 20102015”, Berita Resmi Muhammadiyah, No. 1 Tahun 2015-2020, September 2015. Yogyakarta: PP. Muhammadiyah, 2015

Syuja'. Islam Berkemajuan: Kisah Perjuangan K.H. Abmad Dablan dan Mubammadiyah Masa Awal. Banten: Al-Wasath, 2009.

Wahab, Muhbib Abdul. "Menuju Islam dan Indonesia Berkemajuan", Republika, Rabu, 28 Desember 2016.

Zainuddin, Ahmad. "Revitalisasi Nilai-nilai Sosial Tauhid dalam Merspon Realitas Kekinian", ISLAMICA: Jurnal Studi Keislaman, Vol. 10, No. 2, 2016. 